of instances where sterility occurs in all degrees, with a few exceptional instances where secondary distinctions have been able to develop without being associated with the primary distinction. So that, on the whole, I cannot but candidly consider that all the facts relating to the sterility of natural species are just what they ought to be, if they have been in chief part due to the principle which I am advocating. Mr. Darwin appears to have clearly perceived that there must be some one principle serving to explain all these facts-so curiously related, and yet so curiously diverse. For he says, and he says most truly, "We have conclusive evidence that the sterility of species must be due to some principle quite independent of natural selection." I trust I have now said enough to show that, in all probability, this hitherto undetected principle is the principle of physiological selection. (To be continued.)

\section{RED SUNSETS AND VOLCANIC ERUPTIONS}

$T \mathrm{HE}$ great volcanic eruption in New Zealand raises anew the question of the connection between volcanic eruptions and sunset phenomena arising from attenuated matter in the upper regions of the atmosphere. The theory that the noteworthy sunsets about the end of I 883 were due to the Krakatao eruption has been questioned on the ground that, in many parts of the world, these red sunsets have continued until the present time, though not with the same intensity as in I883. Beautifully variegated sunsets have always been very common in this country. The result was that the sunset phenomena of 1883 did not appear to us as anything new in kind, but only as an intensification of something with which we were already familiar. In order to reach a decisive conciusion we must have observations made in regions where the upper atmosphere is exceptionally free from vapours or other attenuated matter. The advent of such matter can then be detected when it could not be detected at other places. Among such regions I would suggest South Africa, especially the Cape of Good Hope. During my brief residence there in November and December of 1882 , nothing was more striking than the extreme whiteness and purity of the western twilight. If such a twilight is there the rule during the whole year, then any diffusion of volcanic vapour in the upper atmosphere must produce a very striking effect. I would therefore suggest to observers in that region the value of precise information on this point, especially with a view of learning to what extent, and within what time, the red sunsets of 1883 disappeared, and whether any such phenomena now reappear as the result of the volcanic eruption in New Zealand.

S. NEWCOMB

\section{MR. FORBES'S EXPEDITION TO NEW GUINEA}

NATURALISTS will be glad to learn that a collection of natural history objects has been sent to England by our countryman Mr. H. O. Forbes, who has been doing good work on the Astrolabe Mountains in southeastern New Guinea. Unfortunately a lack of proper support appears to have greatly crippled the efforts of this energetic traveller, who fears that he may be compelled to abandon his proposed expedition to Mount Owen Stanley, the ascent of which was the primary object of his explorations on leaving England. The disaster which befel Mr. Forbes at Batavia, where the boat with all his equipment for the expedition was capsized and everything lost, will be fresh in the recollection of our readers (see NAture, vol. xxxii. p. 552), and it is only by the utmost display of courage and energy, and by a large pecuniary sacrifice on his own part, that Mr. Forbes has been able to fit out an expedition to New Guinea from Brisbane. It is to be hoped that the great Societies of this country and Australia will not allow this expedition to come to an end for lack of funds. Mr. Forbes has shown what he can do in the cause of science, and a little timely help would now enable him to conduct the work of exploration on which his soul is bent and bring it to a successful issue. It is not generally known in this country that during his last expedition to the Malay Archipelago he expended more than $600 /$. of his own money in endeavouring to render his expedition more complete, and nothing but a little generous encouragement is needed to enable him to sustain the serious pecuniary loss which has befallen him in his attempt to reach Mount Owen Stanley. At the time of writing, we hear that there is a prospect of Australia coming to the rescue and aiding Mr. Forbes towards the attainment of his object, and we trust that England will also do something for a man who, as an explorer and a naturalist, has reflected credit on his country.

The district recently explored by Mr. Forbes has been visited before by Mr. Goldie and Mr. Hunstein, the latter of whom has procured some remarkable novelties among the Birds of Paradise, which have been recently described by Dr. Finsch and Dr. Meyer (Zeitsch. Ges. Orn. ii. pp. 369-39r). Hunstein has indeed penetrated further than Mr. Forbes was able to do on the present occasion, as the latter has as yet only worked the Sogeri district from a height of 1000 to 5000 feet, and this only in the rainy season.

Among the many interesting species found by $\mathrm{Mr}$. Forbes in the Sogeri district may be mentioned Harpyopsis nova-guinece, Salvad, Charmosyna stella, Meyer, Psittacella pallida, Meyer (scarcely to be distinguished from P. brehmi of Mount Arfak), P. madaraszi, Meyer, Eos incondita, Meyer, Parotia lawesi, Ramsay, Lophorina minor, Ramsay, Paradisornis rudolphi, Meyer, Amblyornis subalaris, Sharpe, Paradisea raggiana, Sclater, Microdynamis parra, Salvad (Rhamphomantis rollesi, Ramsay), Melidectes emilii, Meyer, Rallicula rubra, Schlegel, and many other notable species, amongst which are two which appear to be undescribed, viz.,

$$
\text { Melirrhophetes batesi, sp. n. }
$$

M. similis $M$. ochromelani, Meyer, sed fasciâ supraoculari cervina distinguendus. Long. tot. 9'3, culm. 1'35, alæ 48 , caudæ $4 \cdot 2$, tarsi I'I 5 .

$$
\text { Pseudogerygone cinereiceps, sp. n. }
$$

P. similis P. flavilaterali, Gray, ex Novâ Caledoniâ, sed minor, et rectricibus haud subterminaliter albo-fasciatis distinguenda. Long. tot. $3^{\circ} 4$, culm. $0^{*} 4$, alæ I*9, caudæ $\mathrm{I} \cdot 2$, tarsi 0.65 .

It was a little unfortunate for $\mathrm{Mr}$. Forbes that Mr. Hunstein should have visited the Horse-shoe Range so shortly before the arrival of the former in New Guinea, but it says much for the complete way in which Mr. Forbes does his work of exploration, that he should have obtained specimens of nearly every one of the new species discovered by Mr. Hunstein. Unfortunately the Birds of Paradise were out of colour at the time of his visit, but the specimens sent are of great interest, as showing the moults and changes of plumage in these birds. Of the extraordinary species known as Prince Rudolph's Bird of Paradise (Paradisornis rudolphi) with blue wings and blue flank-plumes, Mr. Forbes secured only one, apparently a female. As these surprising novelties have been discovered in the Astrolabe Range, which has an elevation of less than 5000 feet, what prizes and discoveries may not be awaiting the explorer if he reaches Mount Owen Stanley with an altitude of 13,000 feet? May he succeed!

R. Bowdler Sharpe

THE PERSISTENT LOW TEMPERATURE

$\mathrm{I} T$ is seldom that the weather maintains such a decided persistency for temperatures below the average conditions. Week after week passes, and the thermometrical 
records are monotonously alike in chronicling low temperatures over the whole country.

The Weekly Weather Reports issued by the Meteorological Office are compiled from observations at stations fairly representative of the whole of the British Islands, and the results are grouped into twelve districts. These returns show that the low temperature is not limited to any special area of the United Kingdom, but is common to every part. From the middle of May to the beginning of August there was only one week, ending July 5, in which the temperature was above the average in the western districts of England, Ireland, or the Channel Islands, whilst in the period of seven months from January 4 to August 2 the temperature in the north-west and south-west of England and in the Channel Islands has only been above the average in three weeks-March 29 , May 10 , and July 5 ; and averaging the results for the whole of the British Islands, these are the only weeks in which the resultant temperature was above the average, and may fairly be considered the only warm periods during the seven months.

This persistency of low temperature is to be traced over the whole of the past twelve months, commencing with the beginning of August 1885. To the three warm weeks already mentioned there must be added those of November 9 and 30, December $2 \mathrm{I}$, and January 4, making seven in all, and these represent the only warm weeks throughout the entire period, and are the only weeks in which the mean temperature for the whole of the British Islands was above the average.

The following table, which is compiled from the Weekly Weather Reports for the fifty-two weeks ending August 2, 1886 , shows the number of weeks with the temperature in excess or defect of the average, and the extent of the deficiency for the several districts. The averages used for the comparison are for the twenty years $1861-1880$.

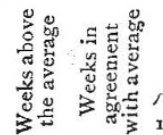

Weeks below the average

S'cotland, N.

Scotland, E.

England, N.E.

England, E.

… $\quad$ I$$
6
$$

10
15

$3^{\circ}-4^{\circ} \quad 5^{\circ}-6^{\circ}$

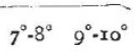

Midland Counties .... II

England, S. $\quad$... Io

Scotland, W. $\quad$... 10

England, N.W.

England, S.W.

Ireland, $\mathrm{N}$.

Ireland, S.

Channel Islands

$$
\text { ... } 7
$$$$
\text { … } 7
$$$$
\text { … } 9
$$$$
\text { … } 8
$$

16
10
13
11
13
10
9
12
13
15
10

6
7
8
12
9
6
5
11
7
5
7
5

$\begin{array}{ll}2 & - \\ 3 & - \\ 3 & - \\ 1 & 3 \\ 2 & 3 \\ 2 & 3 \\ 4 & - \\ 2 & 3 \\ 2 & 3 \\ 4 & - \\ 2 & 1 \\ - & 1\end{array}$

From this it is seen that the highest number of weeks during the year with the temperature above the average was twelve in the north-east of England, whilst the lowest was six in the Channel Islands.

Throwing the weekly values together so as to form a monthly result, it is seen that November 1885 is the only month of the last twelve in which the resultant temperature for the whole of the British Islands was above the average, and then the excess only amounted to $\mathrm{I}^{\circ}$; of the remaining eleven months, one was in agreement with the average, one had a defect of $1^{\circ}$, four had a defect of $2^{\circ}$, three a defect of $3^{\circ}$, and two a defect of $4^{\circ}$. The three consecutive months having the greatest deficiency of temperature were January to March, the defect averaging fully $3^{\circ}$ for the entire period.

The rainfall for the same twelve months was above the average during the six months September, October, and November $\times 885$, and January, May, and July I886, the excess being larger in England than in Scotland or Ireland. It was in fair agreement with the average in
March and April, and in defect in the four months August and December 1885 , and February and June 1886. CHAS. HARDING

\section{THE PLIOCENE DEPOSITS OF NORTH- WESTERN EUROPE}

$\mathrm{I}$ the series of stratigraphical monographs on which the Geological Survey is engaged, the preparation of the volume treating of the Pliocene deposits has been assigned to Mr. Clement Reid. In pursuance of the plan on which these works are being written, I requested him to visit some of the Continental regions where deposits of corresponding age are best developed, and a personal acquaintance with which would extend his knowledge of their English equivalents. $\mathrm{He}$ has accordingly spent some time recently in Belgium and Holland, and among other localities visited the well-known exposures of the Diestian beds around Diest and Antwerp. The sections there laid open, the remarkable assemblage of organic remains contained in them, and the peculiar condition in which the shells at Diest have been preserved led him on his return to this country to re-examine the curious deposit of ironstone at Lenham, on the North Downs, in which, so far back as $185^{\prime} 7$, the occurrence of Pliocene shells was announced by Prof. Prestwich. Doubt was cast upon this identification of the age of these shells: by many geologists they were looked upon as Lower Eocene, though their original discoverer has consistently maintained his opinion. Mr. Reid has now been fortunate enough to obtain a considerable number of additional species that settle beyond doubt the Pliocene age of the Lenham beds, and thus confirm the view of the veteran Oxford Professor. The establishment of this point raises questions of such wide interest in geology that I feel justified in anticipating the appearance of the memoir in which the facts will be detailed. At my request Mr. Reid has drawn up the following report, which briefly embodies the facts he has brought to notice, and touches upon some of the problems which they suggest.

ARCH. GEIKIE

Some years ago Prof. Prestwich announced the discovery of beds of Pliocene age at a height of over 600 feet on the North Downs (Quart. Fourn. Geol. Soc., vol. xiv. p. 322). The bad preservation of the fossils, however, led Mr. S. V. Wood, who examined them, to mark all the species as doubtful, though he was inclined to agree that they were probably Pliocene. Owing to the unsatisfactory nature of the palæontological evidence, and apparently also to an accidental mixture of Eocene fossils from other localities, this discovery has been discredited or ignored, though Prof. Prestwich himself has always maintained its accuracy.

Recently, while preparing an account of the British Pliocene beds for the Geological Survey, it has been necessary for me to examine any outlying deposits which have been considered to belong to that period. For this purpose I paid a second visit to Lenham, near Maidstone, having several years ago examined that locality with no satisfactory result, owing to the obscurity of the sections. A number of blocks of fossiliferous ironstone were obtained from pipes in the Chalk-just as the original specimens were found. These were brought to London, carefully broken up, and impressions taken from the moulds of fossils with which the ironstone was filled. By this means a series of casts was obtained very much better than the obscure impressions so doubtfully determined by Mr. S. V. Wood. The result of the examination of these fossils has thoroughly corroborated Prof. Prestwich's view, for there is not a single Eocene species among them. With two or three exceptions they are all known Pliocene forms; some are new to England, though occurring in France and Italy. 